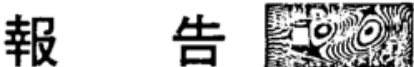

\section{8 年9月16日 宮城県名取市闒上地区に発生した竜巻による建物被害 \\ Building Damage caused by a Spout (Tatsumaki) \\ in Natori City on September 16, 1998}

佐々木和彦*1 植松 康*2 野澤壽一*3

Kazuhiko SASAKI, Yasushi Uematsu, Toshikazu NOZAWA

\section{1.はじめに}

1998 年 9 月 16 日午前 5 時半頃,宮城県名取市䦥上（ゆ りあげ）地区で竜卷が発生し, 一部の地域に建物被害を もたらした。この竜巻は台風5号に関連して発生したも のと考えられる。台風 5 号は, 大型で並みの強さの台風 であり, 同日午前 4 時, 静岡県御前崎付近に上陸し, 名取 市で竜巻が発生した時には関東地方を通過していた。名 取市は, 台風中心から見て北北東の方向約 $380 \mathrm{~km}$ に位 置し, 竜巻の発生しやすい台風の外圈降雨帯にあったと 推定される。

筆者らは,この竜巻による建物被害を調査したので, 以下にその概要を報告する。

\section{2. 被災地域の状況}

䦥上地区は, 名取市の東端に位置し, 太平洋に面して いる（Fig. 1)。東に閶上魚港があり，瓦亘き屋根の住 家が多い低層住宅地である。被災地域には,県道 129 号 線が名取川に添って闒上魚港から約 $1 \mathrm{~km}$ 通っており (Fig. 2参照)，その周囲には比較的古い住家が建ち並んでいる。 また，住家（店舖付を含む）以外には魚介類加工等の工 場が数軒建っている。

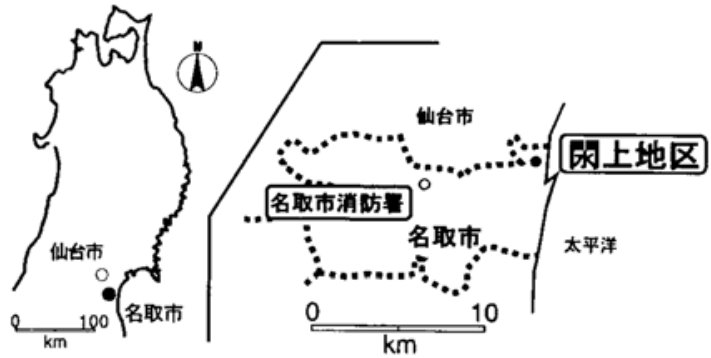

Fig. 1 閶上地区と名取市消防署の位置 (Locations of Yuriage area and Natori Fire Station)
3. 台風 5 号及び被害発生当時の気象状況

3. 1 台風 5 号の概要

Fig. 3に台風 5 号の経路を示す。この台風は, 9月 16 日 4 時, 御前崎付近に中心気圧 $965 \mathrm{hPa}$ で上陸した。竜 巻が発生した 5 時 30 分頃は, 時速 $45 \mathrm{~km}$ で関東地方を 北北東に進んでいた。その後も強い勢力を保ったまま 北北東に進み, 12 時頃名取市に最も近づいた。15時に は青森県八戸市付近に達しそその後温帯低気圧に変った。

$* 1$ 東北大学大学院工学研究科都市・建築学専攻 大学院生

Graduate Student, Dept. of Architecture and Building Science, Tohoku Univ.

*2 東北大学大学院工学研究科都市・建築学専攻 助教授 工博

Assoc. Prof., Dept. of Architecture and Building Science, Tohoku Univ., Dr. Eng.

*3 東北工業大学工学部建築学科 助手

Research Assoc., Dept. of Architecture, Tohoku Institute of Technology

（原稿受理：平成10年12月15日） 


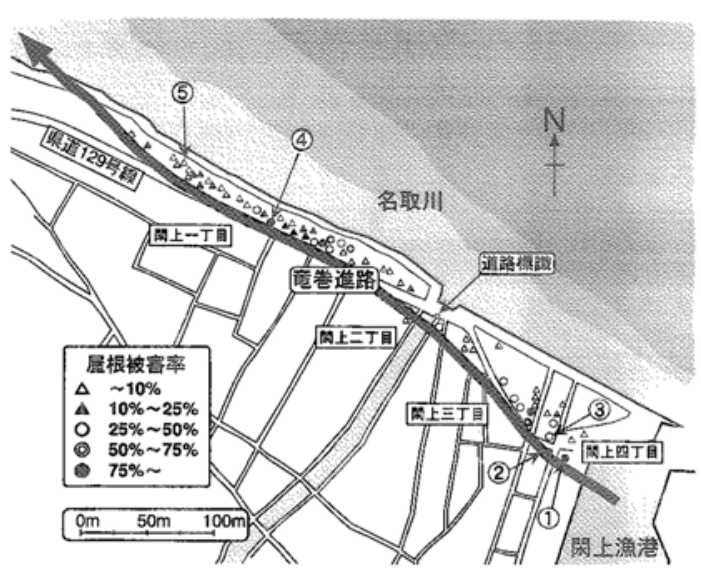

Fig. 2 屋根被害を受けた建物の位置と竜巻進路予想 (Locations of the damaged buildings and the predicted track of Tatsumaki)

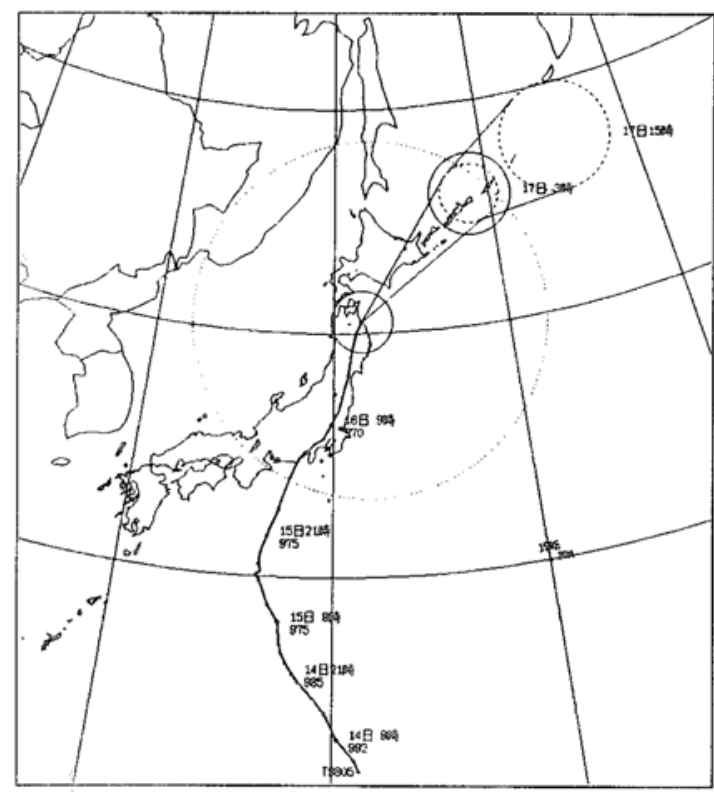

Fig. 3 台風進路図（気象庁仙台管区気象台提供）

(Track of Typhoon No.5 in 1998)

\section{2 閔上地区周辺の風速}

闒上地区に最寄りの風観測地点は, 西方向約 $5 \mathrm{~km} に$ 位置する名取市消防署であり (Fig. 1参照), 風向・風 速計の設置高さは地上 $15 \mathrm{~m}$ である。Fig. 4 に平均風速 および最大瞬間風速の時刻歴 (1時間毎) を示す。なお, 平均風速および最大瞬間風速の評価時間は，それぞれ 10 分および 1 秒である。竜巻が発生した午前 5 時半頃の風 速は最大値よりかなり低く，風速記録に竜巻の影響は見 られない。

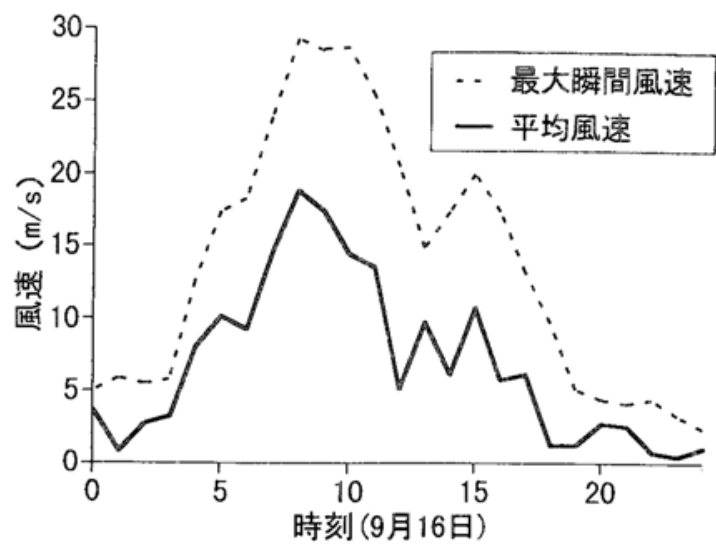

Fig. 4 名取市消防署における平均風速および最大瞬間 風速の記録（1998年9月16日）

(Time history of the mean and gust wind speeds measured at Natori Fire Station on 16 September, 1998)

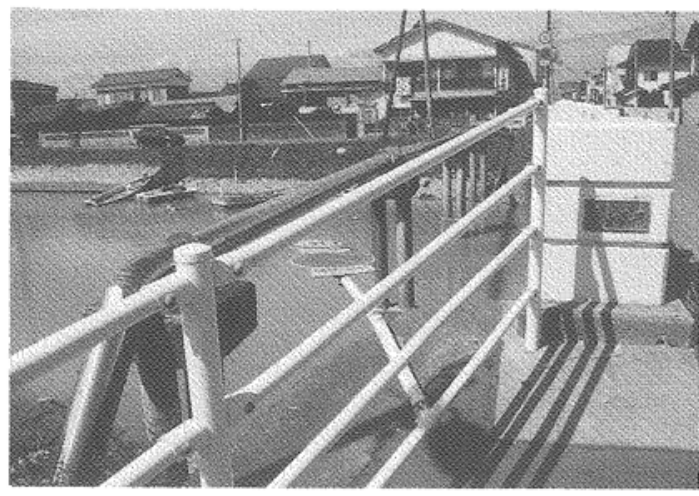

Photo. 1 折れ曲がった道路標識

(Damage to a road sign)

被災地域には,橋の上に設置されていた道路標識が竜 巻によって西側に倒れるという被害があった（Photo. 1)。その位置をFig. 2 に示す。この地点の風速值を道 路標識の耐力（ベースにおける支柱の全塑性モーメン ト) から計算すると, $36 \mathrm{~m} / \mathrm{s}$ 以上であったと推測される。

\section{4. 被害状況}

名取市役所がまとめた被害状況（1998年9月 22 日現 在）を以下に示す。

（1）住 家：半壊 1 梀, 一部破損 88 棟

（2）非 住 家：半壞 5 棟, 一部破損 36 棟

（3）人的被害：無し

ここで,「半壊」とは, 住家の損壊が䍡だしいが, 補修 すれば元通りに使用できるもので, 具体的には破壊部分 
が, その住家の延べ床面穦の $20 \%$ 以 $70 \%$ 未満のもの， 又は住家の主要構造部の被害額か，その住家の時価の 20 \%以上 $50 \%$ 未満のものである。また,「一部破損」とは， 全壊及び半壞に至らない程度の破損で, 補修を必要とす る程度のものである。ただし,ガラスが数枚破損した程 度のごく小さいものは除く。

\section{5. 建物被害}

\section{1 被害の概要}

竜巻発生の三日後 (1998年9月19日), 筆者らは比較 的被害の大きい建物を対象として被害調查を行った。な お,調督には日本風工学会・風災害研究会において提案 されている簡易調查表”を用いた。

建物被害には屋根尊き材や外壁材の剥離や飛散, 空ガ ラスやシャッターの破損等があったが, その中で屋根被 害が特に目立った。屋根被害は，瓦の一部がずれるとい う㪕微なものから, 屋根全体が剥ぎ取られたものまで広 範囲に及んでいる。屋根被害率を5段階に分け, 被害建 物の位置をプロットすると, Fig. 2 に示す如くである。 被災地域は, 名取川右岸河口付近であり, 閶上漁港から 名取川に沿って, 幅約 $50 \mathrm{~m}$, 長さ約 $1 \mathrm{~km}$ の長細い地域 である。県道 129 号線の北側に被害が集中し, 南側には 目立った被害は見られなかった。竜巻の規模は，屋根瓦 が吹き飛ばされた状況から, 藤田スケールF1に相当す ると考えられる。また, 以下に示す事実より, 竜巻の回 転方向は半時計周りであり, その経路はFig. 20矢印で 示すようなものであったと推定される。すなわち, 䦥上 漁港内で発生し, 名取川右岸地域を県道 129 号線に治っ て西北西方向に約 $1 \mathrm{~km}$ 移動し, その後名取川に抜けて 消滅したものと考えられる。

（1）午前 5 時半頃, 閶上漁港内で水しぶきと共に竜巻が 発生し,その後西に進んだという目丵証言。

（2）漁港近くを車で通りかかった人が竜巻を確認し，西 方向に逃げたところ, 竜巻が追いかけるように進ん できたという目擊証言。

（3）漁港近くの倉庫や工場（Fig. 2中, (1)および(3)で示 した建物）の屋根惪き材や外壁の破片が閶上二丁 目の方まで飛散していた。

(4) 前述の道路標識が西方向に倒れた。

(5) Fig. 2中, (5で示した銭湯の煙突が西方向に倒れた。

（6）Fig. 2にはプロットされていないが, 県道129号線 の南側に位置する住宅数楝において, 屋根瓦が東方 向にずれるという被害もあった。

\section{2 被害例}

以下，顕著な被害のあった建物を示す。それぞれの位 置はFig. 2 中に番号(1)〜(5)で示されている。 (1)倉庫 (Photo. 2)

闒上魚港に位置し, 竜巻が最初に被害を及ぼした建物 と思われる。屋根苟き材の7割以上が竜巻によって剥ぎ 取られだ。破損した壁や屋根蕞き材の破片は北西方向 に200〜300m以上飛ばされていた。

(2)食品加工場 (Photo. 3)

上記の倉庫前道路の西側に位置する。竜巻時の飛来物 による壁, 窓ガラス, シャッタ一等の被害が著しい。 (3)鉄工所 (Photo. 4)

上記の倉庫前道路の北西側に位置する。外壁および屋 根がプラスチック製の波板であり, 竜巻に切り刻まれた ような被害が発生した。数日後,この建物は撤去された。 (4)住家 (Photo. 5)

この住家は, 住家として最大の被害が発生したもので

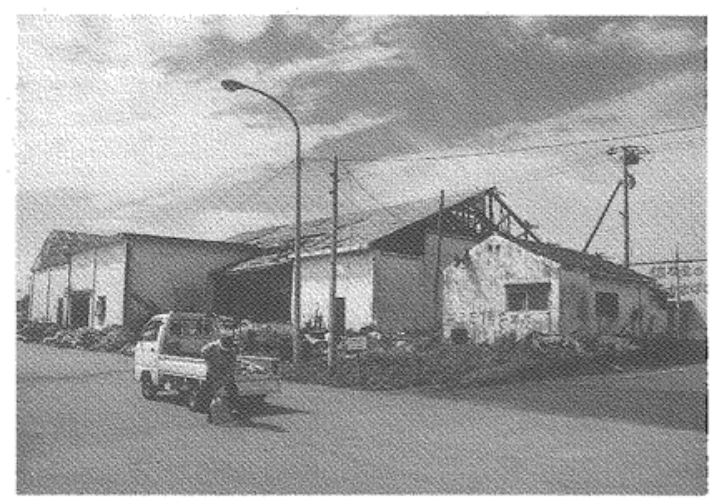

Photo. 2 倉庫の被害

(Damage to a warehouse)

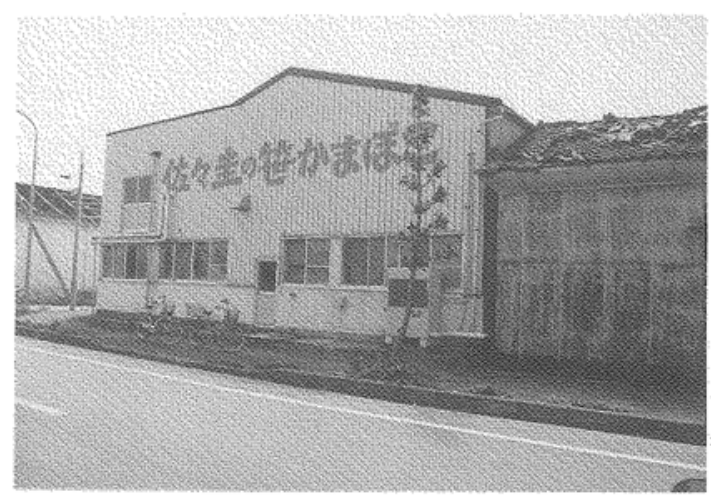

Photo. 3 食品加工場の被害

(Damage to a food-processing factory) 


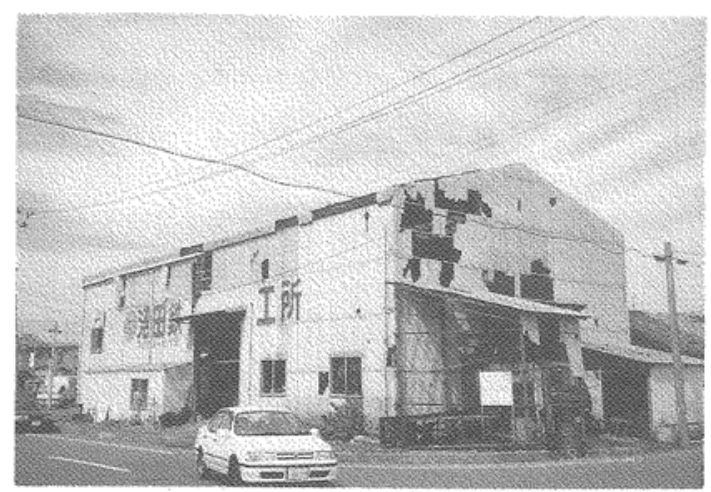

Photo. 4 鉄工所の被害

(Damage to a steel-rib fabricator)

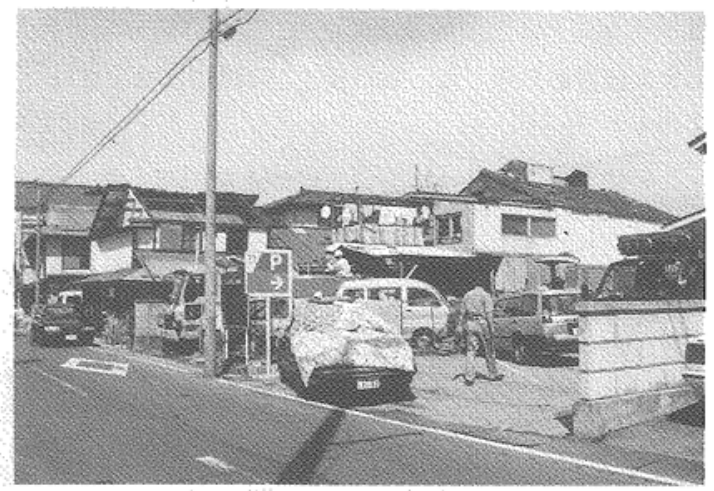

Photo. 5 住家の被害

(Damage to a residential house)

ある。屋根の瓦はほとんど剥ざ取られ, 一部は屋根ごと 飛ばされた。窓ガラスも多数破損した。

(5)銭湯 (Photo. 6)

約 $7 \mathrm{~m}$ の煙突が立っていたが, 強風により西方向に倒 れ, 建物に寄りかかった。

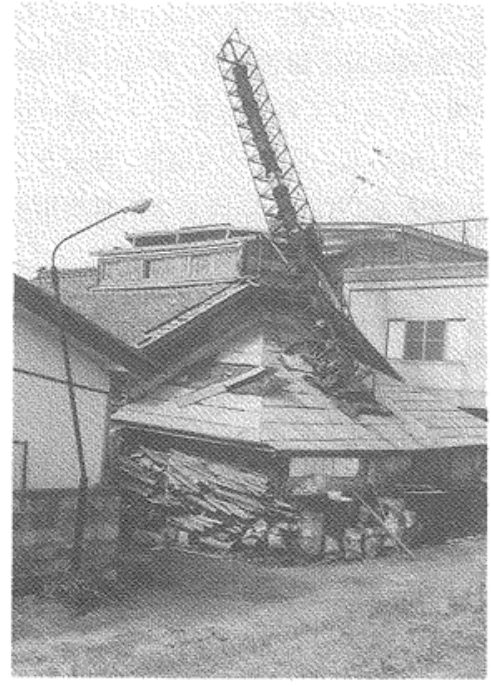

\section{Photo. 6 銭湯の被害}

(Damage to a bathhouse)

\section{6. おわりに}

以上のように童巻はごく限られた地域に被害をもたら した。今後, 被害の実態を明らかにするため, 被害の有 無も含め, より詳細な調査を行い, 被宫と建物構造との 関連の検討や, 風速の推定を行う予定である。それらの 結果は別の機会に公表したい。

最後に, 調查に当り, 仙台管区気象台, 名取市役所, お よび名取市消防署よりデー夕提供等の協力を頂いた。こ こに記し, 感謝の意を表する。

\section{参考文献}

1）大熊武司, 植松 康, 野村卓史 : 日本風工学会による 風災害謂查・低減活動, 日本風工学誌第78号, 1999. 